\title{
ADDIN
}

https://journal.iainkudus.ac.id/index.php/Addin

ISSN: 0854-0594; E-ISSN: 2476-9479

Volume 14, Number 2, August 2020: 241-274

DOI: $10.21043 /$ addin.v14i2.3624

\section{Archaeological Study of Islamic History in Minahasa}

\section{Irfanuddin Wahid Marzuki}

Balai Arkeologi Daerah Istimewa Yogyakarta, Indonesia

irfanudin.wahid@kemdikbud.go.id

\section{Abstract}

This article shed light on an archaeological study about the spread of Islam in the land of Minahasa of North Sulawesi Province. As the biggest ethnic group living in North Sulawesi Province, most of its people are Christians. Islam arrival in Minahasa carried by Arab traders, habaib from Hadramaut, and political prisoners (Kiai Modjo, Tuanku Imam Bondjol, Kiai Ahmad Rivai, and Tubagus Buang). As a discipline with a focus on ancient cultural heritage, archaeology works based on the material culture taking the form of artifacts, ecofacts, or features. This study enables an investigation on Islamic history in Minahasa based existing physical cultural. The archaeological study on the history of spread of Islam in Minahasa is of novelty since the previous researches of the same topic were mostly conducted through manuscript and archive study. The result of the field observation reveals that the influence of Islamic culture in Minahasa comprises of some Islamic settlements, mosques, and Islamic cemetery. The influence of Islamic culture in Minahasa has a different character between coastal and inland areas.

Keywords: Islamic Culture, Archaeology, Minahasa.

\section{Abstrak}

KAJIAN ARKEOLOGIS SEJARAH ISLAM DI MINAHASA. Artikel ini membahas penelitian tentang pengaruh kebudayaan Islam di tanah Minahasa, Provinsi Sulawesi Utara berdasarkan kajian arkeologi. Minahasa merupakan wilayah etnis terbesar di Provinsi Sulawesi 
Utara dengan mayoritas penduduk beragama Kristen. Masuknya agama Islam di Minahasa dilakukan oleh pedagang-pedagang Arab, habaib dari Hadramaut, dan tahanan politik pemerintah kolonial Belanda (Kiai Modjo, Tuanku Imam Bondjol, Kiai Ahmad Rivai, dan Tubagus Buang). Arkeologi merupakan disiplin ilmu yang mempelajari kebudayaan manusia masa lalu berdasarkan peninggalan fisiknya berupa artefak, ekofak, ataupun fitur. Dengan menggunakan kajian arkeologi, dapat ditelusuri pengaruh Islam di tanah Minahasa berdasarkan peninggalan budaya fisik yang ada. Penelitian mengenai sejarah Islam di Minahasa dengan menggunakan kajian arkeologi secara khusus sampai saat ini belum pernah dilakukan. Penelitian-penelitian sebelumnya menggunakan kajian naskah dan arsip. Hasil pengamatan di lapangan menunjukkan pengaruh kebudayaan Islam di Minahasa, meliputi: pemukiman Islam, masjid, dan pemakaman (kuburan) Islam. Pengaruh kebudayaan Islam di Minahasa memiliki karakter yang berbeda antara wilayah pesisir dan pedalaman.

Kata Kunci: Kebudayaan Islam, Arkeologi, Minahasa.

\section{A. Introduction}

As an ethnic region in North Sulawesi, Minahasa is situated adjacent to Sulawesi Sea and Philippine in the North, Pacific Ocean in the East, Tomini gulf in the South, and Bolaang Mongondow Regency in the West. Minahasa is located at $\mathrm{N} 00^{0} 51^{\prime} 00^{0}-1^{0} 51^{\prime} 40^{\prime \prime}$ and E $124^{0} 18^{\prime} 40^{\prime \prime}-125^{0} 21^{\prime} 30^{\prime \prime} .1$ The word Minahasa itself is derived from the word "mina" and "esa" meaning to become united, or become one. ${ }^{2}$ This unity refers to the unity of eight sub ethnics namely: Tonsea, Tombulu, Tondano, Totemboan, Tonsawang, Ratahan, Ponosakan, and Bantik. The word Minahasa came to be used officially in the official document of Dutch colonial government since 1789, prior to which the term Landstreek van Manado was used to refer to this ethnic region. ${ }^{3}$ Nowadays, Minahasa region is divided into seven

${ }^{1}$ Tim Penyusun, Adat Istiadat Daerah Sulawesi Utara (Jakarta: Proyek Penelitian dan Pencatatan Kebudayaan Daerah Departemen Pendidikan dan Kebudayaan, 1977/1978), 110.

${ }^{2}$ David Henley, "Nationalism and Regionalism in Colonial Indonesia: the Case of Minahasa", Indonesia: the East Indies and the Dutch 55, no. 1 (1993), 91.

${ }^{3}$ E.C. Godée Molsbergen, Geschiedenis van de Minahasa tot 1829 (Weltevreden: Landsdrukkerij, 1928), 137. 
administrative regions namely Minahasa Regency, South Minahasa Regency, Southeast Minahasa Regency, North Minahasa Regency, Manado City, Bitung City, and Tomohon City (Figure 1).

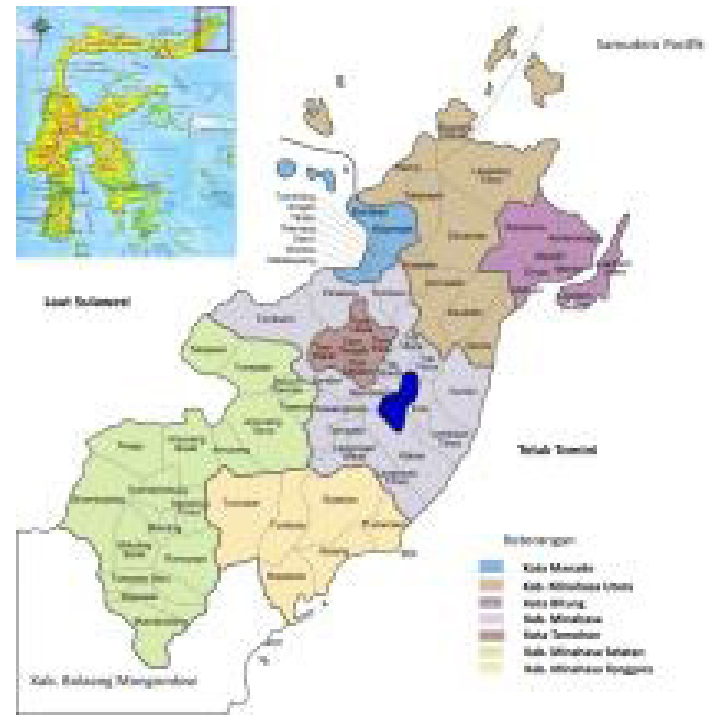

Figure 1

The Map of Research Location

(www.theminahasa.net, with some modifications by writer)

The Minahasa inshore (The Celebes Sea) becomes the trade route since XV century. ${ }^{4}$ There were two maritime routes through Minahasa inshore, those are the route from Chinese mainland through Philippine-Sulu-Northern Nusa Islands (Sangir Talaud) and north Moluccas. Meanwhile, the other one is the route from Moluccas through Northern Kalimantan, Celebes sea, to northern Nusa Islands (Sangir Talaud) and Northern Moluccas. These routes then were used by European sailors to reach Ternate. ${ }^{5}$ The route through the Celebes sea was considered important by European

${ }^{4}$ David Henley, "Nationalism and Regionalism in Colonial Indonesia: the Case of Minahasa", Indonesia: the East Indies and the Dutch 55, no. 2 (1993), 27. M.J. Schouten, Leadership and Social Mobility in a Southeast Asian Society Minahasa 1677-1983 (Leiden: KITLV Press, 1998), 39.

${ }^{5}$ Tim Penelitian, "Pusat Peradaban Minahasa Perkembangan Hunian dan Budaya Minahasa”, Laporan Penelitian, Balai Arkeologi Manado, 2012, 178. 
as they could use Northern wind avoiding Java sea and Flores sea which were still under the control of Javanese kingdoms, besides they could shorten the sea shipping range to Moluccas to 600 mil. $^{6}$

Besides functioning as the source of state treasury, Minahasa also provided the great number of manpower for Dutch colonial. Many young men of Minahasa were listed as colonial troops. In 1820s, 1400 Minahasan became the troop ${ }^{7}$ There were two factors why the young wanted to be the troop, namely economic and social factors. Becoming a troop means changing the destiny and thus promising the better future. Besides, it could also raise their family social status. ${ }^{8}$ Before colonial era, Minahasa was the peripheral area of Makassar and Ternate kingdoms. Meanwhile, during VOC and Dutch colonial, it became a remote outback and far from the interest of central government in Batavia although it was still wellsupervised, so that it turned to be the exile colony from Java and Sumatera such as Pangeran Diponegoro, Kiai Modjo, Kiai Hanafi, Tubagus Buang, Tuanku Malim Mudo, and Imam Bondjol.

Minahasa prominently introduced the Western style education system and became the center of Protestant Christianity and Catholic Minahasa during the colonial era. In 1860 in Minahasa, it was easy to find 150 schools comprising of 12 state-owned schools, 30 sekolah rakyat (school built for community) and 108 zending schools. The schools and zending in Minahasa were interconnected. The schools were used for zending mission spreading Christianity and only the Christians were allowed to study in these schools. Bibles became the obligated reading book under NZG (Nederlandsch Zendeling Genootschap). ${ }^{9}$

${ }^{6}$ A. Lapian, Orang Laut Bajak Laut Raja Laut: Sejarah Kawasan Laut Sulawesi Abad XIX (Jakarta: Komunitas Bambu, 2009), 66.

${ }^{7}$ Jan Sihar Aritonang and Karel Steenbrink, A History of Christianity in Indonesia (Leiden: Brill, 2008), 402. H. Palar, Wajah Lama Minahasa (Bogor: Yayasan Gibbon Indonesia, 2009), 54.

${ }^{8}$ R.S. Kipp, "Two Views of the Minahasa: or Whatever Happened to the Poors, Heathen Bushnatives", The Journal of Asia Studies 63, no. 3 (2004), 614. H. Palar, Wajah Lama Minahasa, 61-62.

${ }^{9}$ M.J. Schouten, Leadership and Social Mobility in A Southeast Asian Society Minahasa 1677-1983, 112-113. Jan Sihar Aritonang and Karel Steenbrink, A History of Christianity in Indonesia, 421. 
Even though Islamic History of Minahasa has been addressed by many researchers, the archaeological approach makes this study a considerably distinct one from others. Indeed, the novelty and appeal of this research lie on its newly used archaeological approach. Moreover, the potentials of Islamic cultural heritage in Minahasa have not been much revealed and observed so far. Thus, it is expected that through this study, the archaeological Islamic heritage in Minahasa will be well preserved as the witness of Islamic development in Minahasa.

This research unveils the history of the spread of Islam in Minahasa using archaeological approach. Archaeology is a discipline with a concern on ancient human culture based on the material culture. Overall, the ancient cultural heritage can be classified into three categories namely:

1. Artifacts, this can be defined as a natural material wholly or partially turned into useful materials by the ancestors. It may take the form of stone axes, flakes, and beads;

2. Ecofacts, this term may refer to a natural material utilized by the ancestors, such as bones, charcoals, and pollens;

3. Features, this can be defined as a permanent artifact which cannot be moved from its site without destroying it. For instance: settlement pattern, building structure, burial grounds, and floor remnants.

In order to gather information dealing with the spread Islam spread in Minahasa, the data on ancient cultural heritage are interpreted to make them as if "talk" and reconstruct the cultural history of the ancestors. Archaeology is the primary supplier of cultural reconstruction.

On the basis of the foregoing explanation, this research mainly aims at:

1. Reconstructing the cultural history. For this purpose, the archaeologist must be able to rediscover the ancient cultural heritages spread in many sites. This will be followed by 
sorting out the discovered ancient cultural heritages based on the aspect of form, space (where the heritage lies), and time (when the heritage originates);

2. Reconstructing way of life. For this purpose, archaeologist must at least be able to explain the culture of the materials based on functional aspect. This stage will be achieved through contextual analysis by looking at the relation between one material to another, between the materials with the sites, between one site to another, and between the sites with their environment;

3. Illustrating the process of cultural changes. To attain the third purpose, the archaeologist must have an insight on the cultural processes to be able to demonstrate how and why a particular culture of ancient human in the past experienced cultural changes. ${ }^{10}$

An archaeological approach of Islamic study gave birth to a novel research topic, namely Islamic Archaeology. Islamic Archaeology may select the closest topic to reality based on the material Islamic culture. It is through Islamic archaeology that we can reveal the cultural diversity in a certain region begetting high civilization. ${ }^{11}$ In addition, Islamic archaeology is also one of instrumental analyses to trace back Islamic history in Indonesia. ${ }^{12}$ Defines Islamic history as some events or occurrences taking place in relation to Islamic religion. ${ }^{13}$ The purpose of Islamic archaeology does not only study religious ceremonies, burial system, but also studies the location where a cemetery is located, tomb, house, and gravestone. ${ }^{14}$ The scope of Islamic history embraces the historical process of Islamic growth, development, and spread, the important

\footnotetext{
${ }^{10}$ L.R. Binford, An Archaeology Perspective (New York: Seminar Press, 1972), 104.

${ }^{11}$ Hasan Muarif Ambary, Menemukan Peradaban Jejak Arkeologis dan Historis Islam Indonesia (Jakarta: Logos Wacana Ilmu, 1998), 7-8.

${ }^{12}$ Ambary.

${ }^{13}$ Abuddin Nata, Metodologi Studi Islam (Jakarta: PT Raja Grafindo Persada, 2003), 315.

${ }^{14}$ Uka Tjandrasasmita, Arkeologi Islam Nusantara (Jakarta: Kepustakaan Populer Gramedia, 2009), 210.
} 
figures behind Islamic religion dissemination, and the history of development and decline of the Moslems.

\section{B. Discussion}

Minahasa is known as one of the regions in Indonesia which is mostly occupied by Christians, leaving a relatively small portion for Moslems. For many people Minahasa and Christianity are inseparable. There is probably no other region in Indonesia where so many people emphasise the close relationship between local or ethnic identity and Christianity. ${ }^{15}$ There are two underlying reasons why Islam religion is not well developed and less desirable by Minahasa people, namely: the drained condition of Minahasa people after the war against Spain and the claim of Loloda King from Bolaang Mongondow to be the King of Manado. ${ }^{16}$ The undeveloped Islamic religion in Minahasa is supported by the illustration of Minahasa land in Portuguese and Spanish version, stating "good climate, fertile land, and without Moslems" ${ }^{17}$ Apparently, there has been an attempt to bring Islamic religion to this land in the middle of 16 century which was defeated by the Portuguese. ${ }^{18}$

Thus, it is still unclear when Islamic religion can reach Minahasa and who disseminated it, especially in the coastal areas. This is in contrast to the dissemination of Islamic religion in the rural areas which is known to be brought by the Dutch political prisoners exiled in Minahasa. Palar notes that in XVII century, Islamic religion reached Minahasa through two paths, that are: (1) Ternate path towards Sangir islands, Bolaang Mongondow, and the coastal area of Minahasa; (2) South Sulawesi path towards Gorontalo. ${ }^{19}$ On the other hand, Taulu argued that Islamic religion

${ }^{15}$ Jan Sihar Aritonang and Karel Steenbrink, A History of Christianity in Indonesia, 419.

${ }^{16} \mathrm{H}$. Palar, Wajah Lama Minahasa, 139.

${ }^{17}$ Jouke S. Wigboldus, "A History of the Minahasa C 1615-1680", Archipel Année 1987 34, no. 1 (1987), 67.

${ }^{18}$ Ilham D. Makkelo, Kota Seribu Gereja: Dinamika Keagamaan dan Penggunaan Ruang di Kota Manado (Yogyakarta: Penerbit Ombak, 2010), 98.

${ }^{19} \mathrm{H}$. Palar, Wajah Lama Minahasa, 137. 
came into Minahasa in 1684 along with the laborers brought by the Dutch to build a fort in Manado. ${ }^{20}$ Other saying states that Islamic religion infiltrated Minahasa in XVII century owing to the influence of Ternate Kingdom. Initially, the Islamic believers in Manado were the immigrants from Ternate, Tidore, Makian (North Maluku), and Hitu. They made a living through fishing all along the North and South coast of Minahasa and preserved their caught in some locations, either in some small islands off the coast or in some remote areas in Minahasa land. This caused some initial contact with the natives of Minahasa although not intensively. ${ }^{21}$ According to Prof. Hasan Jan, the chairman of Great Mosque of Awwal Fathul Mubien foundation, the initial Islamic preachers in Manado were the Habibs of Hadramaut who reached Ternate in advance. ${ }^{22}$ Besides those foregoing paths, Islamic religion was also carried by the Arabic tradesmen who came to Minahasa in $1740 .^{23}$ Islamic spread in Minahasa according the author carried by Arabic tradesmen and Habib form Hadramaut. Besides for trade, Arabic tradesmen also aimed had a goal greatness of Islam, different with Ternate, Bolaang Mogondow, and Gorontalo people who embraced Islam but not spread Islamic religion.

Based on some opinion from the scholar, the author argues that the inclusion of Islam in Minahasa carried out three channels: by trade, political, and sociocultural pathways. The trade route was carried out by Middle Eastern traders, political channel were carried out by the political prisoners of the Dutch colonial who were exiled to Minahasa, and the socio cultural route was carried out by migrants from around Minahasa (Ternate, Tidore Makassar, Bugis, Bolaang Mongondow, Gorontalo, and Sangir Talaud).

${ }^{20}$ H.M. Taulu, Masuknya Agama Islam di Sulawesi Utara (Manado: Yayasan Manguni Rondor, 1977), 9.

${ }^{21}$ Tim Penelitian, "Pusat Peradaban Minahasa Perkembangan Hunian dan Budaya Minahasa", Laporan Penelitian, Balai Arkeologi Manado, 2012, 111.

${ }^{22}$ Irfanuddin Wahid Marzuki, "Nisan Tua Kompleks Pekuburan Islam Tuminting, Manado", Jurnal Kapata Arkeologi 5, no. 8 (2009), 45.

${ }^{23}$ Ilham D. Makkelo, Kota Seribu Gereja: Dinamika Keagamaan dan Penggunaan Ruang di Kota Manado, 99. 
The evidence of Islamic culture in the archaeological relics in Minahasa can be grouped into three, namely: the establishment of Islamic settlement, mosque, and cemetery.

\section{The Establishment of Islamic Settlement in Minahasa}

During the Dutch colonial, there was a policy of grouping the settlement based on the ethnic. This policy was based on the China rebellion in 1740 . This rebellion made the Chinese could no longer stay inside the city fort and thus were obliged to live as a group in a certain area out of the city supervised by troops. ${ }^{24}$ This notion was also applied to other ethnics (Arab, India, and indigenous). In order to support this policy, in 1830 the act to manage the separation among ethnics of colonialized people and the urban planning/land use was issued. ${ }^{25}$ This condition also happened in Minahasa, where the settlement was classified using ethnic base, as for Dutch and borgo (meztico) staying in strategic location in city center, while the foreign east (Chinese and Arabs) lived in peripheral areas and in traditional settlement out of town.

Geographically, Islamic settlement in Minahasa can be classified into two classifications which are: coastal settlement and rural areas (Figure 2). Coastal settlement embraces those coming from around Minahasa (Ternate, Tidore, Bugis, Makasar, Gorontalo), and Arab who had settled in Minahasa. The Islamic settlements in the rural areas of Minahasa were the settlement of some political captive of the Dutch who were brought from Java and Sumatera, particularly located in Tondano, Pineleng, and Tomohon. ${ }^{26}$

${ }^{24}$ E. Leushuis, Panduan Jelajah Kota-kota Pusaka di Indonesia (Yogyakarta: Penerbit Ombak, 2014), 12.

${ }^{25}$ Leushuis.

${ }^{26}$ H. Palar, Wajah Lama Minahasa, 98. Ilham D. Makkelo, Kota Seribu Gereja: Dinamika Keagamaan dan Penggunaan Ruang di Kota Manado, 98. 


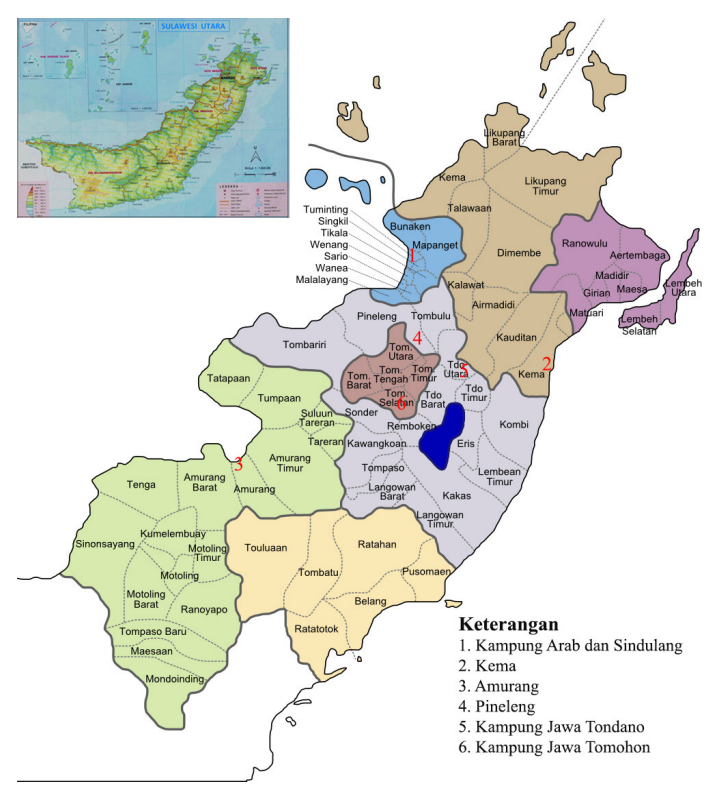

Figure 2

Islamic Settlement in Minahasa

(www.theminahasa.net, with some modifications by writer)

Prior to the arrival of the Dutch colonial government political captives, there had been two locations of Islamic settlements in Manado particularly in: Arabic Village (Kampung Arab) and Islamic Village Sindulang. Interestingly, although it is located in the district of Manado, Kampung Arab was directly governed by Manado Resident through Manado controller and was not subjected to the law of bumiputera (natives). ${ }^{27}$ They originally settled in Kampung Islam Tuminting before making the settlement of their own nearby Amsterdam Fort and the market or port later known as Kampung Arab. ${ }^{28}$ Kampung Arab is situated at the coordinate N 010 $29^{\prime} 45^{\prime \prime}-$ $01^{\circ} 29^{\prime} 46^{\prime \prime}$ and E $124^{\circ} 50^{\prime} 47^{\prime \prime}-124^{\circ} 50^{\prime} 48^{\prime \prime}$. When Manado City was functioned as Gemeente in 1919, Kampung Arab was governed

\footnotetext{
${ }^{27}$ H. Palar, Wajah Lama Minahasa (Bogor: Yayasan Gibbon Indonesia, 2009), 144.

${ }^{28}$ Ilham D. Makkelo, Kota Seribu Gereja: Dinamika Keagamaan dan Penggunaan Ruang di Kota Manado, 99.
} 
by Burgemeester (the mayor) of Manado. ${ }^{29}$ Kampung Arab is also referred to as Kampung Melayu Manado or Letter $H$, governed by a Moslem Lieutenant who was always positioned as the second lieutenant in Schutterij garrison of Manado. By the late of 1800, the number of Moslem schutterij in Manado had accounted to 97 people. In 1840 the Moslem Lieutenant position in Manado was held by Joedoe Kasoemo alias Montaram, until the year 1850 when he was substituted by Djoar. In 1853 the Moslem Lieutenant as well as Wijkmeester of Letter $\mathrm{H}$ was Ong Buntjo. Afterwards, in the end of 1850 Baba Sankilang served as the Lieutenant until March 1862 when he was replaced by Kitjil Alie. ${ }^{30}$

When Manado city became Gemeente in 1919, the area of Kampung Arab was under the administration of Burgemeester (mayor) Manado. It was unknown when the Kampung Arab emerged. In 1866 there were only 11 Arabs in Manado. In 1868 they became 16 people, while the significant rise was in 1930 when the number reached 585 people (315 males and 270 women). ${ }^{31}$ Administratively, today Kampung Arab is known as Kelurahan (Administrative Village) Istiqlal. In addition to Kampung Arab, there were some other Islamic villages located across the river of Todano namely Kampung Islam Sindulang. Kampung Islam Sindulang was a former transit for Ternate sailors who came to visit Minahasa which later separated from Minahasa settlement and was established as a Kampung Islam. Graafland illustrated the condition of Kampung Islam Sindulang in1885 through the following quotes:

To reach Kampung Islam, we had to go through a huge bridge passing over Manado river, which was a masterpiece of its own.... Upon walking from Kawedanan Manado through Sinkil, via Sindulan, we would arrive at Kampung Islam. ${ }^{32}$

${ }^{29}$ F.E.W. Parengkuan, et al., Sejarah Kota Manado 1945-1979 (Jakarta: Departemen Pendidikan dan Kebudayaan, Direktorat Sejarah dan Nilai Tradisional Proyek Inventarisasi dan Dokumentasi Sejarah Nasional, 1986), 23.

${ }^{30}$ Arsip Inventaris Manado No. 2 XV Tahun 1852-1858, a collection of National Archive of Indonesian Republic.

${ }^{31}$ Interview with Adrianus Kojongian, Tomohon, Maret 7, 2017.

${ }^{32}$ N. Graafland, Minahasa: Negeri, Rakyat, dan Budayanya, transl. Lucy Montolalu (Jakarta: Pustaka Utama Grafiti, 1991), 15. 
Kampung Islam Sindulang is a settlement from several ethnic groups (Ternate, Tidore, Boalang Mongondow, Bugis, and Makassar mixed into one settlement).

In 1830s, the Queen of HB II arrived with her children as they are exiled by the Dutch to Manado. The location of this exile was in the middle of borgo settlement, which was later known as Kampung Kedaton. Kampung Kedaton is the Islamic settlement located in the central city of Manado. The location was chosen to ease the supervision of the exiled. The borgo settlement then was the settlement for local Dutch troops or for European descent (Dutch, Portuguese) with local women.

The Islamic Settlement in Kema was the settlement of the Bugis, Ternate, Makasar, and Gorontalo. Those immigrants initially merely built some small cottages (daseng) to protect themselves when they came visiting the island for a transit after sailing. Long after which, these small cottages gradually developed into a settlement. Islamic religion reached Kema around $1800 .{ }^{33}$ Kema was the port in Minahasa eastern beach which was already popular among foreigners since XVI century. In 1800s, the Kema port was merrier compared to Manado port, and this was because the geographical condition of Kema was safe from sea waves and from pirates of Philippine. The English and American ships were then regularly anchored in Kema Ports to do a trading with the local people. ${ }^{34}$

The condition of the settlement in Kema in 1800s was in a good order, with beautiful gardens. There was one loji which was good for controller and mayor. Besides, the beautifully nice houses were provided for European. The Kema situation was the same as the situation for any European settlement in Indonesia. The Kima citizen in 1874 were 1.623 people, divided into three, Borgo people (Christian and Islam) as many as 1.068 people, the natives as many

${ }^{33}$ Tim Penelitian, "Pusat Peradaban Minahasa Perkembangan Hunian dan Budaya Minahasa", Laporan Penelitian, Balai Arkeologi Manado, 2012, 117.

${ }^{34}$ M.J. Schouten, Leadership and Social Mobility in a Southeast Asian Society Minahasa 1677-1983, 56. 
as 388 people and Dutch, 167 people..$^{35}$ The Islamic settlement in Kema was divided into borgo settlement of European descendants and Minahasa settlement. During the colonial era, Islamic settlement in Kema was known as Kema Leter B which now turns into Kema II.

Islamic religion is known to reach Amurang when the fishermen of Tidore came to the region in groups. It is estimated that they came to the place in 1800s headed by a person named Pati Ali. Afterwards, there were some other groups coming to the place from Ternate led by Saman. In addition to these groups, there were also some Islamic influences brought by Arabic, Gorontalo, and Makassar tradesmen. In the beginning, they settled down in Kampung Bobo, the name of which was derived from the name of trees growing in the surrounding area. ${ }^{36}$

The pattern of coastal Islamic settlement was a blend of the Moslems and the local Christian Minahasa people, a part of those living in Kampung Arab. This is so owing to the diversity in their origins with diverse cultural backgrounds leading to wide variants of settlement pattern.

In the rural area of Minahasa, the Islamic settlements are situated in some locations, namely: Pineleng, Tomohon, and Tondano. The Islamic settlement in Pineleng is an exile of Tuanku Imam Bonjol and his followers. Pineleng Islamic Settlement initially was located in Lota Village, of Pineleng Subdistrict, Minahasa Regency, before moving to Pineleng Village due to the development of the new road of Manado-Tomohon in 1960s. ${ }^{37}$ The new Islamic settlement pattern was adjusted to the local settlement pattern and was acculturated to the local culture.

Other Islamic settlements were in Tomohon, the outback in Minahasa located in the height of 700-800 mdpl, and was surrounded by Mount Lokon (1.689 m) and Mount Mahawu (1.311 $\mathrm{m})$. Tomohon was the district capital led by a local leader entitled

\footnotetext{
${ }^{35}$ N. Graafland, Minahasa: Negeri, Rakyat, dan Budayanya, 471.

${ }^{36}$ Tim Penelitian, "Pusat Peradaban Minahasa Perkembangan Hunian dan Budaya Minahasa”, Laporan Penelitian, Balai Arkeologi Manado, 2012, 114-115.

${ }^{37}$ Interview with F.E.W. Parengkuan, Tondano, February 25, 2016.
} 
"Walikota". ${ }^{38}$ Tomohon also experienced the significant growth, from the tiny remoted village to a city hub of trading in 1850s. Graafland (1991), described the changes in as follows: ${ }^{39}$

This region seemed as being kissed by a wonder wand so that the soil becomes a farmstead, the dirty areas become the clean region, the narrow and harsh track tracks turn to be wide road. The lives and the hustle bustle has put the shy and loneliness aside. The peace and safe rise, not war and fear. The dark kingdom as changed into light and blessed one.

Tomohon even became the centre of European education style, some schools were built during the colonial era of Hindia Belanda. The region of Tomohon in the early century of XIX was described as the area congested with its people, ${ }^{40}$ nevertheless, in the middle of the same century, the number of the people decreased. Wilken (1873), reported that Tomohon was more crowded than the present day, this is mainly because of the immigration. ${ }^{41}$

Those living in Tomohon Islamic settlement were mainly originated from Tubagus Buang descendants, a noble person of Banten Sultanate who fought against the Dutch with his followers (Penghulu Abusalam, Masdjebeng, Mukali, and Maskun). At first, Tubagus Buang was placed in Lotta, Pineleng, but then since he was considered as a menace for the Dutch he was moved to walak Sarongsong in Tomohon. ${ }^{42}$ In addition to Tubagus Buang, Tuanku Malim Mudo from West Sumatera was also another figure who was exiled to Sarongsong. These figures then married the young ladies

${ }^{38}$ A.R. Wallace, “Garis Wallace: Teori Seleksi Alam dan Gempabumi di Minahasa”, G. Miller, Indonesia Tempo Doeloe 1544-1992 (Jakarta: Komunitas Bambu, 2012), 157.

${ }^{39}$ N. Graafland, Minahasa: Negeri, Rakyat, dan Budayanya, transl. Lucy Montolalu (Jakarta: Pustaka Utama Grafiti, 1991).

${ }^{40}$ David Henley, "Nationalism and Regionalism in Colonial Indonesia: The Case of Minahasa", Indonesia: The East Indies and The Dutch 55, no. 1 (1993), 180.

${ }^{41}$ G.A. Wilken, "Het Landbezit in de Minahasa", Mededeelingen van wege het Nederlandsch Zendelinggenootschap (1873), 118. David Henley, "Nationalism and Regionalism in Colonial Indonesia: The Case of Minahasa", Indonesia: The East Indies and The Dutch 55, no. 1 (1993), 180.

${ }^{42}$ H. Palar, Wajah Lama Minahasa (Bogor: Yayasan Gibbon Indonesia, 2009), 141. 
of Minahasa and bore some offspring who developed into Kampong Jawa Saronsong. Initially they settled down in Kayu Payung, a small hill not far away from Kampung Jawa Sarongsong. Given the difficult access of Payung Hill from the city District of Tomohon and small pox dissease, in 1875 the inhabitants moved to Kampung Jawa Saronsong as we know it. ${ }^{43}$ Kampung Jawa Sarongsong is situated at coordinate N $01^{0} 17^{\prime} 38^{\prime \prime}-01^{0} 17^{\prime} 38^{\prime \prime}$ and E $124^{\circ} 49^{\prime} 22^{\prime \prime}-124^{\circ} 49^{\prime} 88^{\prime \prime}$.

The Islamic Tomohon settlement in 1870 only comprised of 10 people, but in 1902 became 160 people. ${ }^{44}$ Islam in Tomohon was spreading through marriage between Moslem (Tubagus Buang, et al.) with women of Minahasa. Besides with Minahasan women, some of the men married to the descendants of Kiai Modjo from Jawa Tondano. The Islamic settlement Sarongsong further faced the development with the arrival of people from Bugis, Gorontalo, Makasar, and Solo in $1900 \mathrm{~s} .{ }^{45}$ In their daily life, the people of Jawa Sarongsong still hold dear the customs of Javanese. They even still using the Javanese language with the dialect of Tombulu Manado Malay.

Islamic Settlement in Tondano is known as Kampung Jawa or Jawa Tondano (Jaton), whose people are 100\% Moslems and who lived in an area surrounded by $99 \%$ of Christian settlements. Tondano was the main city in Minahasa though it was not as large as Manado in XVII century. ${ }^{46}$ In addition, Tondano was prosperous region with fertile soil as the coffee and rice producer. ${ }^{47}$ In 1617, Tondano area was one of the areas in Minahasa which is crowded with its population. This description is given by Scalamonti, cirted by David Henley, ${ }^{48}$ stating that most of the Minahasan people were

\footnotetext{
${ }^{43}$ Tim Penelitian, "Pusat Peradaban Minahasa Perkembangan Hunian dan Budaya Minahasa”, Laporan Penelitian, Balai Arkeologi Manado, 2012, 114.

${ }^{44}$ Adrianus Kojongian, Tomohon Kotaku (Tomohon: Dinas Pendidikan dan Kebudayaan, 2006), 192.

${ }^{45}$ Kojongian.

${ }^{46}$ N. Graafland, Minahasa: Negeri, Rakyat, dan Budayanya, transl. Lucy Montolalu (Jakarta: Pustaka Utama Grafiti, 1991).

${ }^{47}$ Hickson (1889), 212.

${ }^{48}$ David Henley, "Nationalism and Regionalism in Colonial Indonesia: the Case of Minahasa", Indonesia: the East Indies and the Dutch 55, no. 1 (1993), 180.
} 
living around Tondano lake. This is in concord with the note of Bleeker ${ }^{49}$ cited by Limadharma. ${ }^{50}$

Indien men hoort spreken van de geringe bevolktheid der Minahasa, dan bedoelt men voorzeker daarmede niet de Tondanosche hoogvlakte. Daar toch woont het grootste gedeelte der bevolking.

If one hears of the small populations in Minahasa, they certainly do not means in the Tondano plateau. Because the majority of the Minahasa population lives there.

Kampung Jawa Tondano is located at coordinate N $01^{0} 18^{\prime} 28^{\prime \prime}-$ $01^{\circ} 19^{\prime} 03^{\prime \prime}$ and E $124^{\circ} 55^{\prime} 04^{\prime \prime}-124^{\circ} 55^{\prime} 32^{\prime \prime}$, in the northside of Tondano Lake. In the beginning, Kampung Jawa used to be the exile of Kiai Modjo and his followers who were all males and married the women of Minahasa to develop a village. ${ }^{51}$ In 1829, Kiai Modjo and his 63 followers arrived in The East Coast of Minahasa and were brought to Tondano in $1830 .^{52}$

Tondano was chosen as an exile for Kiai Modjo since the place was isolated by the highland of Minahasa, because of the reputation of Tondano people as violent people, and owing to the existence of Dutch military forces in Tondano. ${ }^{53}$ Initially Kampung Jawa was built in disarray, unsystematic pattern, dilapidated with some dim, damp, and dirty cottages. ${ }^{54}$ The early sketch of Kampung Jawa Tondano atmosphere was supported by the report of Manado Commissioner in 1864, stating that the settlements of Kampung Jawa villagers were indistinctively modest with the mosque made of bamboo. ${ }^{55} \mathrm{In}$ the early reign of Jansen Resident (1853-1859) there were some settlement arrangements in order to tidy up the settlement into a

${ }^{49}$ P. Bleeker, Reis door de Minahasa in 1855 (Batavia: Lange and Co., 1856), Volume 1, 90.

${ }^{50}$ Hendrata K. Limadharma, "Tanam Paksa Kopi dan Monetisasi Petani Minahasa, 1822-1870", Thesis, Pascasarjana Universitas Indonesia (UI) Jakarta, 1987, 17.

${ }^{51}$ H. Palar, Wajah Lama Minahasa, 141.

${ }^{52}$ Tim G. Babcock, Kampung Jawa Tondano: Religion and Cultural Identity (Yogyakarta: Gadjah Mada University Press, 1989), 28.

${ }^{53}$ Babcock.

${ }^{54}$ N. Graafland, Minahasa: Negeri, Rakyat, dan Budayanya, 459.

${ }^{55}$ Tim G. Babcock, Kampung Jawa Tondano: Religion and Cultural Identity, 19-20. 
better organization, ${ }^{56}$ build house follow Minahasa houses model, regularly roads, and division ground for each family. ${ }^{57}$ The custom commission reported that there were two Javanese kampong in Tondano, namely Kampung Jawa in the district of Toulimambot and Tegalredjo in Tonsea. ${ }^{58}$ Physically, the settlement pattern of Kampung Jawa Tondano adopted the settlement pattern of Tondano settlement, with cluster pattern which were divided in blocks.

Nonetheless, culturally they are distinct since Kampung Jawa maintains Javanese culture in their way of life. The houses were built in wooden poles or concrete with two stairs at the front and at the rear. Although the settlement pattern of Kampung Jawa resembled that of Minahasa and that it was also governed by the Dutch Colonial Government, there was a distinctive characteristic of Kampung Jawa in terms of its mosque location in the center of the village. In relation this, Prof. Dr. Juddy Obet Waani, M.T. articulated that the settlement pattern of Kampung Jawa Tondano was closely related to the activity of the community and its setting system. This settlement was built with Minahasa characteristics but retaining strong setting of Islamic element. ${ }^{59}$

Interestingly, there are some unwritten norms applied in Jawa Tondano regarding with sale of land. Jawa Tondano community are not allowed to sell their land to the outsiders (non Moslems), which becomes the underlying rationale why until today the inhabitants of Kampung Jawa Tondano is $100 \%$ Moslems. ${ }^{60}$ This is an exceptional condition in Minahasa community who were mostly non Moslems. The Islamic settlements in the rural areas are homogenous by settling their own cluster detached from Minahasa settlement. This

\footnotetext{
${ }^{56}$ Judy Obet Waani, "Sistem Seting Masyarakat Kampung Jawa Tondano: Kajian Terhadap Aktivitas dan Setting pada Permukiman Kampung di Kabupaten Minahasa Provinsi Sulawesi Utara", Thesis, Program Pascasarjana Universitas Gadjah Mada (UGM) Yogyakarta, $2000,39$.

${ }^{57}$ Roger Allan Christian Kembuan, "Bahagia di Pengasingan: Kehidupan Sosial Budaya Masyarakat Buangan di Kampung Jawa Tondano (1830-1908)", Thesis, Program Pascasarjana Universitas Gadjah Mada (UGM) Yogyakarta, 2016, 184.

${ }^{58}$ H. Palar, Wajah Lama Minahasa, 143.

${ }^{59}$ Interview with Prof. Dr. Juddy Obeth Waani, M.T., Manado, March 4, 2016.

${ }^{60}$ Interview with Prof. Dr. Juddy Obeth Waani, M.T., Manado, March 4, 2016.
} 
is so because of their similar background as the political captives of Dutch colonial government and mostly because of their same origins.

\section{Mosque}

Generally, mosques are built in squares with a special chamber for Imam or khatib (preacher). The architecture of mosque throughout the Archipelago is well adjusted to the local culture, and so is the mosque in Minahasa. Here, mosques are built with a mixed between Islamic and the local traditional architecture. The first Mosque in Manado was built very simply with clapboard and thatched roof in 1830. The old mosque had been replaced with a new one without retaining the remnants of the old building and is known as The Great Mosque of Awwal Fathul Mubien, located in the coordinate of $\mathrm{N} 01^{0} 30^{\prime} 23^{\prime \prime}$ and E $124^{\circ} 50^{\prime} 45^{\prime \prime} .^{61}$ This mosque was initially built around the early of 1830 . Originally, the mosque was built in square with some clapboards and thatched roof. ${ }^{62}$ However, today it is turned into a modern concrete building. In addition to Fathul Awwal Mubbien mosque, there used to be other mosque in Kampung Islam Sindulang, yet the mosque was relocated leaving an early mosque foundation today in the middle of Tondano River which will be apparent when the tide is low. ${ }^{63}$
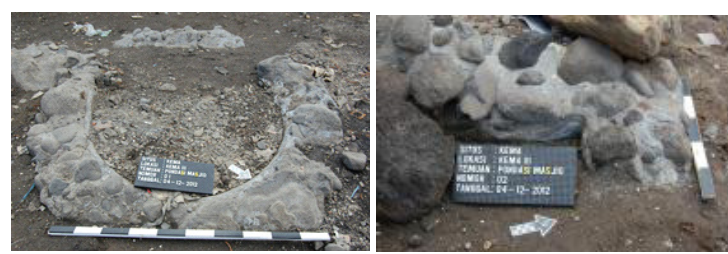

Figure 3

The Foundation of the Old Mosque Located in Kema Village III, Kema

(Doc. Archeological Office of Manado, 2012)

${ }^{61}$ Irfanuddin Wahid Marzuki, "Nisan Tua Kompleks Pekuburan Islam Tuminting, Manado", Jurnal Kapata Arkeologi 5, no. 8 (2009), 45.

${ }^{62}$ Anonymous, "Sejarah Berdirinya Masjid Agung Awwal Fathul Mubien, Kel. Islam, Kec. Tuminting, Kota Manado (Sebagai Masjid yang Pertama di Daerah Minahasa)", Unpublished, 2005.

${ }^{63}$ Diman Surjanto and Dwi Yani Yuniawati U., Penelitian Arkeologi No. 2: Laporan Penelitian Arkeologi Islam di Kotamadya Manado dan Sekitarnya, Sulawesi Utara (Manado: Balai Arkeologi, 1996), 8. 
First mosque in Kema is its foundation which lies on the coastline nearby Adiot Meidy house. The mosque was built by $\mathrm{H}$. Yahya from North Maluku even though the time of its construction remains obscure. In 1936, the mosque building was destroyed by the flood leaving only half of its foundation in the shape of separated parts. This is so due to sea abrasion process taking place after it was abandoned, located on the coordinate of $\mathrm{N} 01^{\circ} 21^{\prime} 78.8^{\prime \prime}$ and $\mathrm{E}$ $125^{\circ} 04^{\prime} 54.8^{\prime \prime}$ (Figure 3). The structure of the first building is in an arch connected to a straight sphere. The diameter of the arch is $80 \mathrm{~cm}$ and the straight sphere is $86 \mathrm{~cm}$. Right in the curved area of $150 \mathrm{~cm}$ distant, there is another structure of a straight shape of $95 \mathrm{~cm}$ length and $30 \mathrm{~cm}$ width of foundation structure. The second foundation lies 1 meter south of the first foundation. This foundation is in the shape of two corners of a rectangular area. The length of the stone structure of the outer part is $130 \mathrm{~cm}$ and the length of the inner part is $70 \mathrm{~cm}$, whilst its width is $30 \mathrm{~cm}$. The third foundation is located 2 meter of the two foregoing foundations. It was in a straight shape which is divided into two different parts. This is triggered by the pressure from above making its position tilted a little bit. The height structure of the foundation remnant is $43 \mathrm{~cm}$ with $50 \mathrm{~cm}$ width and $140 \mathrm{~cm}$ length. Meanwhile, the tilted foundation structure is $103 \mathrm{~cm}$ in length, $60 \mathrm{~cm}$ in width, of the same height. ${ }^{64}$

Kampung Jawa Saronsong Mosque of Tomohon is located in the coordinate of $\mathrm{N} 01^{\circ} 17^{\prime} 50.3^{\prime \prime}$ and E $124^{\circ} 49^{\prime} 23.4^{\prime \prime}$, with 767 $\mathrm{m}$ height above sea level (Figure 4). Presumably, the Mosque was built in 1825 and had been renovated for several times. Kampung Jawa Mosque in Sarongsong is named Nurul Iman Mosque. This mosque was built during the governance of chief village or known as Hukum Tua I Moutong in the village now known as Kampung Jawa Sarongsong. Initially, the mosque was built in square of $6 \mathrm{~m} \mathrm{x}$ $6 \mathrm{~m}$ on the support of four main pillars. The roof was in dome shape with plaited bamboo walls or known as "pitate". During the political turmoil era of Permesta (Perjuangan Rakyat Semesta, The Struggle

${ }^{64}$ Tim Penelitian, "Pusat Peradaban Minahasa Perkembangan Hunian dan Budaya Minahasa”, Laporan Penelitian, Balai Arkeologi Manado, 2012, 118. 
of the People of the Universe) in 1958, the mosque was burned down and rebuilt in 1961. Since the reconstruction after the fire, the mosque was expanded in 1983 with the support of public fund. In 2007, the mosque was enlarged again with the financial aid of The Directorate General of Culture, Ministry of Culture and Tourism before taking the shape as we know today. The current mosque is $18 \mathrm{~m} \times 10 \mathrm{~m}$ large and is divided into two main halls, namely: the first hall of $14 \mathrm{~m} \times 10 \mathrm{~m}$ large; and the hall for congregation praying of the females of $4 \mathrm{~m} \times 10 \mathrm{~m}$ large. Meanwhile, the overall width of the mosque is of $20 \mathrm{~m} \times 20 \mathrm{~m}$ large..$^{65}$

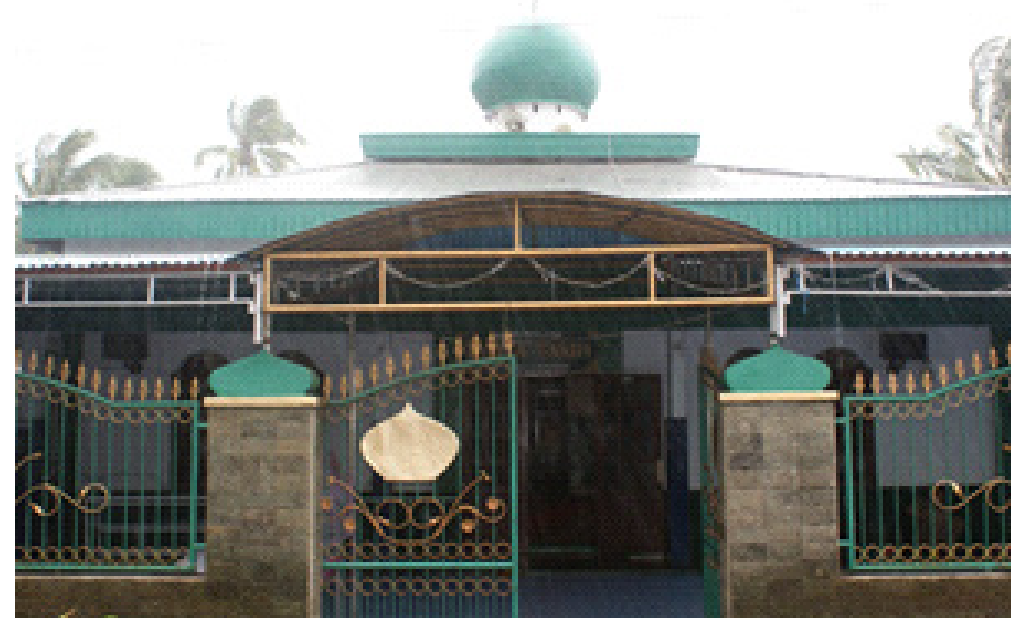

Figure 4

Nurul Iman Mosque of Kampung Jawa Sarongsong, Tomohon

(Doc. Irfan, 2012)

The Mosque of Kampung Jawa Tondano applies a mixture of Islamic and Javanese architecture, located in the coordinate of N 01018'37" and E 124055'10" (Figure 5). In the early years, the mosque was built very modestly with some woods and bamboo in 1868. In 1884 the old building was renovated using some bricks

\footnotetext{
${ }^{65}$ Tim Penelitian.
} 
and cements and with four pillars (soko guru). The roof was made to resemble the overlapping roof of most of Javanese mosques. In addition to the main building, there was also a tower for calling the prayers (azan) separated from the main building. The mosque was built permanently with bricks and cements in $1972 .{ }^{66}$ The Mosque of Kampung Jawa Tondano is named Al-Falah Mosque. The existence of a mosque in Kampung Jawa Tondano is also described by Graafland stating that by 1860 there had been a mosque for praying in Kampung Jawa Tondano. ${ }^{67}$ Despite the reconstruction performed by Amal Bhakti Moslem Pancasila Foundation (Yayasan Amal Bakti Muslim Pancasila, YAMP), the characteristic of the old building with its four pillars soko guru was retained. Besides the soko guru, the mosque of Kampung Jawa Tondano, is well known to utilize bedug (a drum) and kentongan to call the Moslem to conduct congregation prayer during the praying time.
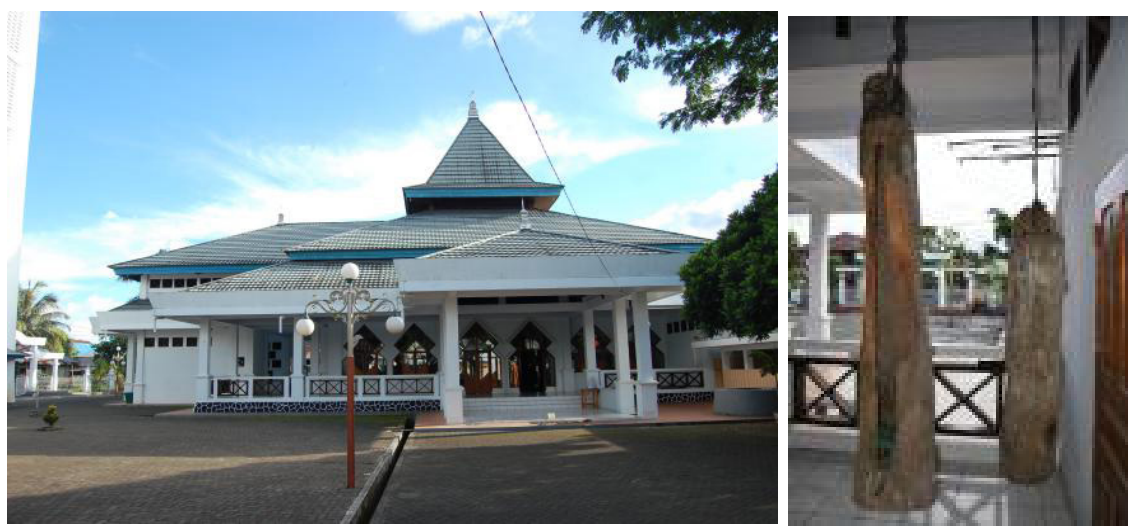

Figure 5

The Mosque of Al-Falah Kampung Jawa Tondano

(Doc. Archeological Office of Manado, 2012) and the kentongan inside the mosque (Doc. Irfan, 2016)

${ }^{66}$ Tim G. Babcock, Kampung Jawa Tondano: Religion and Cultural Identity (Yogyakarta: Gadjah Mada University Press, 1989), 19-20.

${ }^{67}$ N. Graafland, Minahasa: Negeri, Rakyat, dan Budayanya (Jakarta: Pustaka Utama Grafiti, 1991), 458. 


\section{Islamic Cemetery}

Another noteworthy cultural heritage in Minahasa is the Islamic cemetery. From an archaeological point of view, ancient cemetery can be used as a tool to uncover some things related to identity. Figures buried, placement patterns tombs, ornamental pattern identification, building chronology tomb and also can be known development Cultural supporters of the past. ${ }^{68}$ Minahasa community originally was strange to the cemetery as that in the Islamic cemetery. This is so since in terms of spatial planning, the traditional Minahasa people knew nothing about burial ground. When one of their family members passed away, the people would just bury the corps around the house yard. The tradition of separating the location of cemetery from the settlement came to be known by the traditional Minahasa people in $1820 .{ }^{69}$ At first, they buried the dead body in a stone tomb known as waruga, in a shape of a cube with a lid on its top (Figure 6). Waruga is a communal cemetery, which means that one waruga may contain the corpse of a whole family. This is proven by the finding of more than one corps inside one waruga. To bury the corpse with waruga, instead of burying it inside the ground, the people will just leave the waruga in the house yard. The waruga burial system was later banned by the colonial Dutch government in 1890, owing to the outbreak of cholera epidemic in Minahasa, taking so many lives of Minahasa people. ${ }^{70}$ As a substitute, people were obliged to bury their dead family member in the ground.

${ }^{68}$ Effie Latifundia, "Jejak Budaya pada Nisan Kuna Islam di Kuningan", Al-Turas 21, no. 1 (2015), 32.

${ }^{69}$ Interview with H.B. Palar, Tomohon, February 27, 2016.

${ }^{70}$ F.E.W. Parengkuan, “Kuburan Sebagai Obyek Pengkajian Sejarah”, Makalah Seminar Arkeologi (Manado: Balai Arkeologi Manado, 2000), 5. 


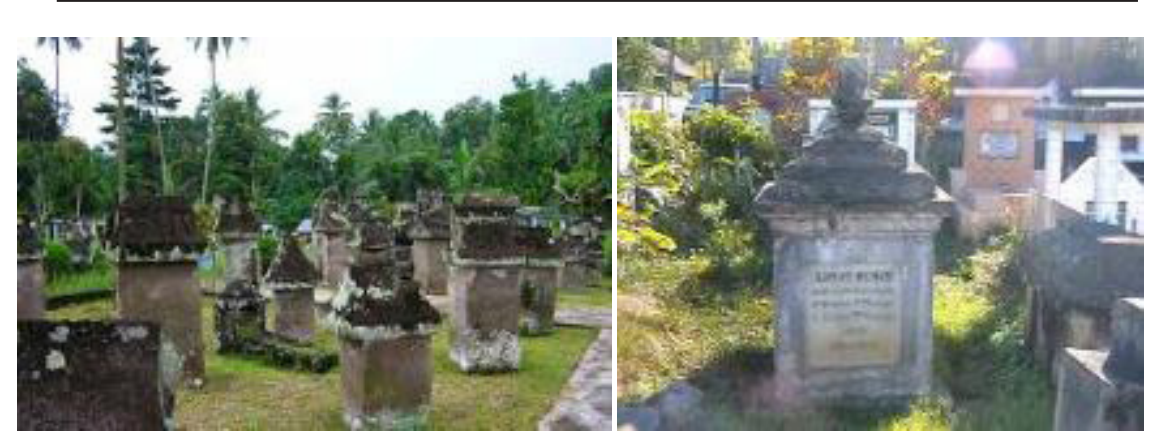

Figure 6

The shape of waruga burial (left) and the shape of the Minahasa tombstone

(Doc. Irfan, 2015)

The structure of Minahasa people tomb resembles that of the European tomb and is different from Islamic tomb (Figure 6). In general, the Islamic burial ground building has three elements completing each other, namely sepulcher (known as kijing in Javanese language) and rectangular basic with some variation of forms. On top of the tomb, commonly there is a gravestone in the form of a sign made of wood, stone, or metal with some certain forms. The gravestone may be positioned in the head or in both of the head and the foot. To complete the grave, sometimes, people will build a shield of cupola to protect the grave from rainwater. ${ }^{71}$

The tombs during Islam era positioned the head part facing the north and the foot part facing the south. The tomb in Indonesia absorbs the Hindu-Buddha influences and some of the tombs were thought of being imported from other country judging from the style and the material. ${ }^{72}$ The original realm was revealed from the phallus shape or styled menhir so that it looked like lingga. Meanwhile, the decoration on the tomb, according to Ambary comes from pre Islam and foreign culture. The foreign influence can be seen from the raw materials of the tomb and the calligraphic existence. For example, the tomb of Samudra Pasai, its raw materials and the calligraphy style

\footnotetext{
${ }^{71}$ Hasan Muarif Ambary, Menemukan Peradaban Jejak Arkeologis dan Historis Islam Indonesia (Jakarta: Logos Wacana Ilmu, 1998), 18.

${ }^{72}$ Halina Budi Santoso, "Catatan Tentang Perbandingan Nisan Kubur dari Beberapa Daerah Indonesia”, Makalah Pertemuan Ilmiah Arkeologi I (Jakarta: Rora Karya, 1980).
} 
were from Cambay. ${ }^{73}$ The cemetery of Indonesia can be classified into decorated and non decorated tomb, as well as fully decorated one. Based on the center of distribution, the Islamic tomb scatters to four areas Sumatera (Aceh and Minangkabau), Jawa (Demak and Troloyo), South Sulawesi (Goa-Tallo, Bone-Soppeng), and Moluccas (Ternate and Tidore). ${ }^{74}$
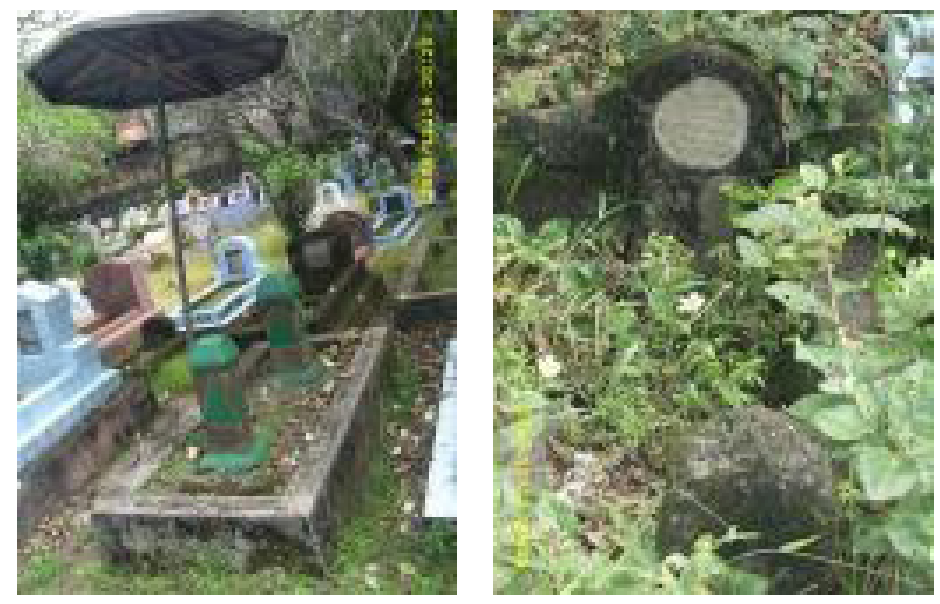

Figure 7

Tomb of Shaykh Sayyid (left) and Syarifah Alawiyah (right)

(Doc. Irfan, 2009)

The Islamic cemetery is located in Tuminting (Islamic cemetery, Arabic tomb, and Elong tomb), Amurang, Jawa Tondano, and Jawa Sarongsong. Islamic cemetery of Tuminting administratively is situated in Bitung Administrative Village Karang Ria, Tuminting Subdistrict, Manado City, and the coordinate of N $01^{0} 30^{\prime} 38^{\prime \prime}$ and E $124^{\circ} 50^{\prime} 51^{\prime \prime}$ (Figure 7). This is an Islamic cemetery of those coming from North Manado. The typology of gravestone can be classified into two kinds: flat and menhir. Some old tombs from the 1800s and early of 1900s can be found in this cemetery, among which are: Shaykh Sayyid bin Alwi bin Umar bin Zen al-

\footnotetext{
${ }^{73}$ Ambary.

${ }^{74}$ Ambary.
} 
Idrus, who died on Sunday 17 Rajab 1285 H (1866 AD), the tomb of Syarifah Alawiyah binti as-Sayyid Shaykh Ahmad bin Alwi bin Abi Bakr bin Salim, who died on Saturday the $24^{\text {th }}$ of Muharram $1333 \mathrm{H}$ (12 December 1914 AD), and the grave of Shaykh 'Aud bin Thoyib Bafadhol. Shaykh Sayyid is believed to be one of the first Islamic religious preachers in this region by the local people. Shyakh Sayyid grave condition has been changed, with tombstones made of cement and with an inscription in Arabic alphabet. In contrast, the gravestone of Syarifah Alawiyah Syaid bint ash-Shaykh Ahmad bin Alwi bin Abi Bakr bin Salim is still pristine, with the old materials and writings remained unchanged. Unluckily, Syarifah Alawiyah grave condition is not well preserved and can hardly be recognized because of the bushes. The grave of Shaykh 'Ud bin Thayyib Bafadhal has been adjusted to the specified tomb size of the present tomb caretaker. The only distinctive feature is the tombstone which is made of cement.

Islamic cemetery of Amurang is located in Bobo Village, Administrative Village Ranoyapo, Lingkungan II, Amurang Subdistrict, South Minahasa, at coordinates N 0110'99" and E $124^{\circ}$ 33'91". The cemetery is situated side by side to the general tomb complex. The old Islamic cemetery part is located in the outer part nearby the sea. The tomb complex was once close to the shoreline and therefore some parts were exposed to marine abrasion so many tombs were lost leaving only handful remaining tombs and eight tombs that can be identified. Most of the tombs are made of stone structure plastered with cement. At the top there is a gravestone with stone and marble materials with an inscription on the gravestone which is partly illegible because of damage. The location of Islamic cemetery was abandoned and moved to a new location in 1929. At that time there were four figures named Samad Rasidin, Amir Schu, Kader Teleh, and Yunus Hakim who purchase piece of land located in the village of Buyungon, Amurang Subdistrict, South Minahasa to be made a Moslem burial ground. ${ }^{75}$

${ }^{75}$ Tim Penelitian, "Pusat Peradaban Minahasa Perkembangan Hunian dan Budaya Minahasa”, Laporan Penelitian, Balai Arkeologi Manado, 2012, 115. 
Kampung Jawa Tondano cemetery is located on Tondata hill with coordinates $\mathrm{N} 01^{0} 18^{\prime} 51^{\prime \prime}$, and E 124055'44", of $730 \mathrm{~m}$ height above sea level. A burial ground on a hill or high land reflects a concept of pre-Islamic burial tradition that still continues to be applied during Islamic period in Java. The burial ground of Javanese Kings is mostly situated on a hill, the concept of which is apparently well applied by the community of Javanese Tondano. In addition to the location of the burial ground, the use of gravestones and headstones also resemble a tomb in Java as most of the tombs in Kampung Jawa use sepulcher (gravestone) as used by the Javanese. Kampung Jawa people call the cemetery with sarean (cemetery in Javanese language). ${ }^{76}$
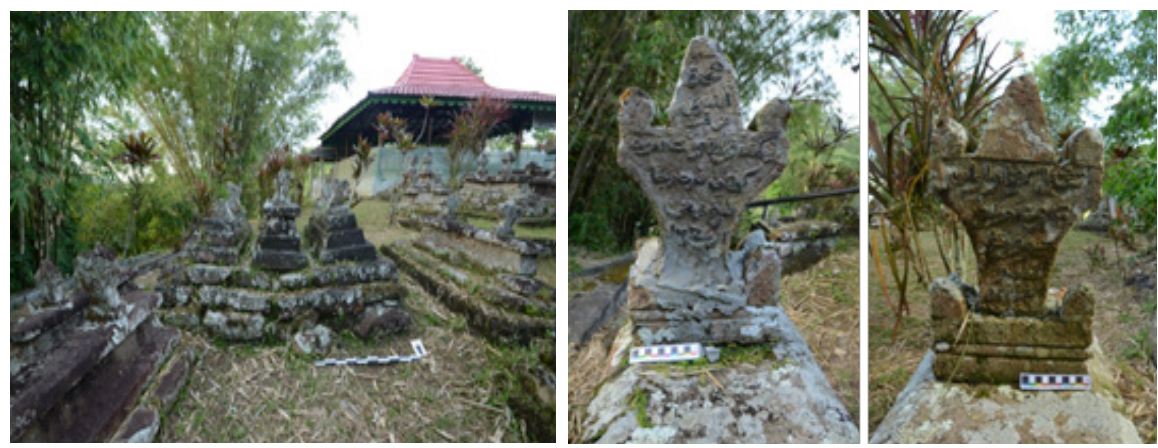

Figure 8

Kiai Modjo burial complex and gravestones in Kiai Modjo burial complex with Arab Jawi inscription

(Doc. Irfan, 2009)

In the gravestone is the inscription with Jawi writings (Arab alphabet but expressing Javanese language). In the early generation, the Javanese influence was clearly evident in the gravestone. Besides its shape, the dating written in the gravestone is still using the Javanese dating. However, because of the ill-mannered condition of

${ }^{76}$ Roger Allan Christian Kembuan, "Bahagia di Pengasingan: Kehidupan Sosial Budaya Masyarakat Buangan di Kampung Jawa Tondano (1830-1908)”, Thesis, Program Pascasarjana Departemen Sejarah, Fakultas Ilmu Budaya, Universitas Gadjah Mada Yogyakarta, 2016, 156. 
the gravestone and the cement coverage on some parts of the tomb makes it difficult to read. The evidence of the Javanese dating in one gravestone is the use of the Javanese pancawara calendar/fiveday-calendar (Pon, Pahing, Wage, Kliwon, Legi), and the mention of Javanese year (Alip, Ehe, Jimawal, Je, etc.). The shape of the tomb in Kampung Jawa Tondano experienced the changes since 1950s, in terms of inscription and the shape. The shape of the tomb becomes simpler and uses cement as the material, while the inscription uses Indonesian (Figure 8). The shape of the gravestone in the burial complex of Kampung Jawa looks like Aceh gravestone type N. According to Daniel Perret and Kamarudin Abd. Razak (1999), the Aceh gravestone can be classified into 16 types (Figure 9)..$^{77}$ The findings of Acehnese stone typology suggest that probably some ulamas from Sumatera and war prisoners were brought and lived in Kampung Jawa Tondano, which then influenced such typology.

Kampung Jawa Sarongsong burial ground is located at the edge of settlements with coordinates N 01017'48" and E $124^{\circ} 49^{\prime} 20^{\prime \prime}$ of $763 \mathrm{~m}$ height above sea level. This burial site lies on a higher ground than the residential location. The current tomb has experienced some changes by the use of brick and cement as well as coated with ceramics. The burial complex of Kampung Jawa Sarongsong is different from other Islamic settlements, where some non-Moslem tombs near the Islamic cemetery location are found. Surprisingly, in that cemetery, the tomb of Tubagus Buang, the founder of Kampung Jawa Sarongsong, is not found. It is possible that Tubagus Buang passed away when the settlement was still at Kayu Payung. Today, the location of his tomb remains a mystery.

${ }^{77}$ Daniel Perret and Kamarudin Abd. Razak, Batu Aceh Warisan Sejarah Johor (Johor Baru: EFEO and Yayasan Warisan Johor, 1999). 

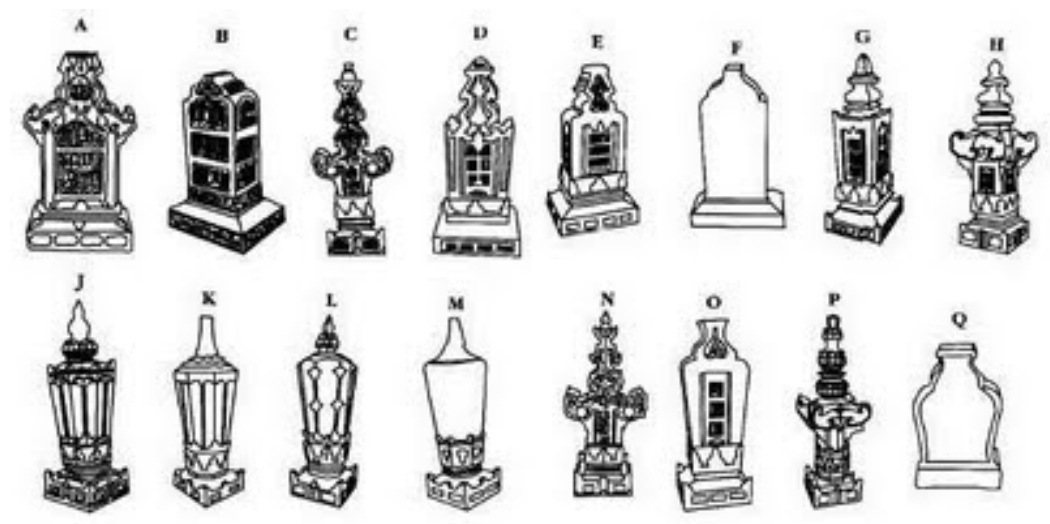

Figure 9

Typology of Aceh gravestone

(Source: Perret and Kamarudin Abd. Razak, 1999: 27)

\section{Conclusion}

It is through archaeological approach that we can unveil the history of Islamic development in Minahasa through the remnants of its material culture. It can be assumed that the Islamic culture acculturated to the local culture of Minahasa in peace despite the fact that there were some different acculturation patterns between the coastal Islamic settlement and the rural one. Unlike the Moslems living in the coastline who have totally mingled with the local tradition, the Moslems in the rural areas still retain the tradition of their origin as shown by the shape characteristic of mosque, the location of the burial ground, and the shape of the tomb.

The archaeological Islamic cultural heritage in Minahasa can be seen in the Islamic settlement, mosque, and Islamic cemetery, whilst there is nothing left from cultural heritage in the form of old manuscript since they were all burnt in blaze during Permesta (Perjuangan Rakyat Semesta, The Struggle of the People of the Universe) rebellion. In general, the Islamic settlement in Minahasa can be classified into two categories namely the coastal settlement and the rural settlement. The coastal settlement took place prior to the rural as there were some immigrants from the areas around Minahasa who settled down in the coastal area of Minahasa. On 
the other hand, the rural Islamic settlement in Minahasa occurred during the colonial Dutch government who brought some political captives into exile in Minahasa in the middle of the $19^{\text {th }}$ century. Unlike the rural one, the coastal Islamic settlement pattern is more heterogeneous since they totally mingle and are mixed with the local culture of Minahasa. Meanwhile, the pattern of the rural Islamic settlement is much more homogeneous forming a separated group detached from the Minahasa people. This difference lies because those living in the coastal areas came from different areas with various multicultural background, whilst those living in the rural were mostly originated from the same region with the same culture and historical background as the Dutch political prisoners. In addition, the Islamic coastal settlements were more exposed to external influence owing to its more opened location. This is in contrast to the Islamic settlement in the rural which still holds the old tradition of their origin firmly as can be seen from their archaeological heritage, mosque and tomb architecture, which remains unchanged.

The mosque architecture of Moslem community in north coast has used new style of architecture. The initial building was usually simple, rectangle shaped with wooden materials, while now has changed into a concrete structure. Nevertheless, though the mosque of the coastal Moslem community has changed, the distinctive features of the Javanese mosque remain, such as four pillars (soko guru), wood gong (kentongan), and leather-made drum (bedug), all for religious purposes. This difference occurs as the cultures of the people inhabiting the place are also different. The coastal people are more open to any changes and they themselves come from different regions, therefore, no sole culture appears significantly. This is different from inland Islamic settlement where most of the people are from Java and thus they do not experience many changes from outside. The mosque architecture still retains the traditional Javanese architecture despite the shifting pattern of the settlement which has been adjusted to the settlement in Minahasa. The location of Islamic cemetery also reflects the Javanese cemetery tradition as 
it is mostly located on a higher ground (hill or mountain) than the location of the settlement.

There is a different choice of cemetery location by those living along coastal settlement and those who live in inland. The location of cemetery in coastal settlement locates outside the settlement and on the flat ground so that it will be easier to visit. Sepulcher (gravestone) and cemetery tombstones used in rural settlement also still retain the shape and material as those used in Java. This is different from the coastal communities who place burial sites around the settlement and use simple shape tomb (gravestone) with brick and cement material. 


\section{REFERENCES}

Ambary, Hasan Muarif. Menemukan Peradaban Jejak Arkeologis dan Historis Islam Indonesia. Jakarta: Logos Wacana Ilmu, 1998.

Anonymous, "Sejarah Berdirinya Masjid Agung Awwal Fathul Mubien, Kel. Islam, Kec. Tuminting, Kota Manado (Sebagai Masjid yang Pertama di Daerah Minahasa)", Unpublished, 2005.

Aritonang, Jan Sihar and Karel Steenbrink. A History of Christianity in Indonesia. Leiden: Brill, 2008.

Arsip Inventaris Manado No. 2 XV Tahun 1852-1858, a collection of National Archive of Indonesian Republic.

Babcock, Tim G. Kampung Jawa Tondano: Religion and Cultural Identity. Yogyakarta: Gadjah Mada University Press, 1989.

Binford, L.R. An Archaeology Perspective. New York: Seminar Press, 1972.

Bleeker, P. Reis door de Minahasa in 1855. Batavia: Lange and Co., 1856.

Graafland, N. Minahasa: Negeri, Rakyat, dan Budayanya, transl. Lucy Montolalu. Jakarta: Pustaka Utama Grafiti, 1991.

Henley, David. "Nationalism and Regionalism in Colonial Indonesia: the Case of Minahasa", Indonesia: the East Indies and the Dutch 55, no. 1 (1993).

Kembuan, Roger Allan Christian. "Bahagia di Pengasingan: Kehidupan Sosial Budaya Masyarakat Buangan di Kampung Jawa Tondano (1830-1908)", Thesis, Program Pascasarjana Universitas Gadjah Mada (UGM) Yogyakarta, 2016.

Kipp, R.S. "Two Views of the Minahasa: or Whatever Happened to the Poors, Heathen Bushnatives", The Journal of Asia Studies 63, no. 3 (2004).

Kojongian, Adrianus. Tomohon Kotaku. Tomohon: Dinas Pendidikan dan Kebudayaan, 2006. 
Lapian, A. Orang Laut Bajak Laut Raja Laut: Sejarah Kawasan Laut Sulawesi Abad XIX. Jakarta: Komunitas Bambu, 2009.

Latifundia, Effie. "Jejak Budaya pada Nisan Kuna Islam di Kuningan”, Al-Turas 21, no. 1 (2015).

Leushuis, E. Panduan Jelajah Kota-kota Pusaka di Indonesia. Yogyakarta: Penerbit Ombak, 2014.

Limadharma, Hendrata K. "Tanam Paksa Kopi dan Monetisasi Petani Minahasa, 1822-1870", Thesis, Pascasarjana Universitas Indonesia (UI) Jakarta, 1987.

Makkelo, Ilham D. Kota Seribu Gereja: Dinamika Keagamaan dan Penggunaan Ruang di Kota Manado. Yogyakarta: Penerbit Ombak, 2010.

Marzuki, Irfanuddin Wahid. "Nisan Tua Kompleks Pekuburan Islam Tuminting, Manado", Jurnal Kapata Arkeologi 5, no. 8 (2009).

Molsbergen, E.C. Godée. Geschiedenis van de Minahasa tot 1829. Weltevreden: Landsdrukkerij, 1928.

Nata, Abuddin. Metodologi Studi Islam. Jakarta: PT Raja Grafindo Persada, 2003.

Palar, H. Wajah Lama Minahasa. Bogor: Yayasan Gibbon Indonesia, 2009.

Parengkuan, F.E.W. "Kuburan Sebagai Obyek Pengkajian Sejarah", Makalah Seminar Arkeologi. Manado: Balai Arkeologi Manado, 2000.

Parengkuan, F.E.W., et al. Sejarah Kota Manado 1945-1979. Jakarta: Departemen Pendidikan dan Kebudayaan, Direktorat Sejarah dan Nilai Tradisional Proyek Inventarisasi dan Dokumentasi Sejarah Nasional, 1986.

Perret, Daniel and Kamarudin Abd. Razak. Batu Aceh Warisan Sejarah Johor. Johor Baru: EFEO and Yayasan Warisan Johor, 1999.

Santoso, Halina Budi. "Catatan Tentang Perbandingan Nisan Kubur dari Beberapa Daerah Indonesia”, Makalah Pertemuan Ilmiah 
Arkeologi I. Jakarta: Rora Karya, 1980.

Schouten, M.J. Leadership and Social Mobility in a Southeast Asian Society Minahasa 1677-1983. Leiden: KITLV Press, 1998.

Surjanto, Diman and Dwi Yani Yuniawati U. Penelitian Arkeologi No.

2: Laporan Penelitian Arkeologi Islam di Kotamadya Manado dan Sekitarnya, Sulawesi Utara. Manado: Balai Arkeologi, 1996.

Taulu, H.M. Masuknya Agama Islam di Sulawesi Utara. Manado: Yayasan Manguni Rondor, 1977.

Tim Penelitian. "Pusat Peradaban Minahasa Perkembangan Hunian dan Budaya Minahasa”, Laporan Penelitian, Balai Arkeologi Manado, 2012.

Tim Penyusun. Adat Istiadat Daerah Sulawesi Utara. Jakarta: Proyek Penelitian dan Pencatatan Kebudayaan Daerah Departemen Pendidikan dan Kebudayaan, 1977/1978.

Tjandrasasmita, Uka. Arkeologi Islam Nusantara. Jakarta: Kepustakaan Populer Gramedia, 2009.

Waani, Judy Obet. "Sistem Seting Masyarakat Kampung Jawa Tondano: Kajian Terhadap Aktivitas dan Setting pada Permukiman Kampung di Kabupaten Minahasa Provinsi Sulawesi Utara", Thesis, Program Pascasarjana Universitas Gadjah Mada (UGM) Yogyakarta, 2000.

Wallace, A.R. "Garis Wallace: Teori Seleksi Alam dan Gempabumi di Minahasa”, G. Miller, Indonesia Tempo Doeloe 1544-1992. Jakarta: Komunitas Bambu, 2012.

Wigboldus, Jouke S. "A History of the Minahasa C 1615-1680", Archipel Année 1987 34, no. 1 (1987).

Wilken, G.A. "Het Landbezit in de Minahasa", Mededeelingen van wege het Nederlandsch Zendelinggenootschap (1873). 


\section{Interview}

Interview with Adrianus Kojongian, Tomohon, Maret 7, 2017.

Interview with F.E.W. Parengkuan, Tondano, February 25, 2016.

Interview with H.B. Palar, Tomohon, February 27, 2016.

Interview with Prof. Dr. Juddy Obeth Waani, M.T., Manado, March 4, 2016. 